REGULAR ARTICLE

\title{
DETERMINANTS OF RURAL FARMERS PREFERENCE FOR CASH-LESS TRANSACTIONS IN IMO STATE
}

\author{
Igwe Ikenna UKOHA *, Ada HENRI-UKOHA, Okwudili IBEAGWA, Ubong A. ESSIEN, \\ Maryann N. OSUJI
}

Address:

Department of Agricultural Economics, Federal University of Technology Owerri Nigeria

*Corresponding author: aiukoha@yahoo.com

\begin{abstract}
The preference for cash-less transaction by Nigerians cannot be exaggerated, but despite its patronage, there exist limited access and utilization of the cash-less technologies among farmers in South-East Nigeria. The study analysed the determinants of rural farmers' preference for cash-less transactions in Imo state, South-East Nigeria. Multi-stage sampling technique was employed in selection of 100 farmers for the study. The determinant of rural farmers' preference for cash-less transactions in Imo State, was achieved using logit model. The result of the analysis showed that age (5\%), gender (10\%) education levels of the farmers (1\%), user friendliness of technologies $(5 \%)$, transaction charge $(5 \%)$ and security of transactions $(5 \%)$ were found to be the major determinants of farmers preference for cash-less transactions based on their levels of significance. Centred on the findings, the study recommended the strengthening of the use of cash-less transaction by farmers by providing a favourable financial environment through better orientation programs, so as to enable a smooth transition from a cash-based economy to cash-less economy.
\end{abstract}

Keywords: Cash-Less, Farmers, Preference, Logit

JEL: C50, F00, Q14

\section{INTRODUCTION}

Nigeria, as an agrarian economy has significant proportions of its farmers in the rural areas that lack adequate capital to realize their production potentials. In Nigeria, the financial system consists of a regulated formal sector, which is controlled using government legislations and an un-regulated informal sector. The nature and operation of the informal financial sector makes it difficult to be regulated and controlled. The consequence is that, financial leakages are high making it difficult to access funds for investment purposes. This encumbers economic growth and development. Subsequently, these hitches of the cash based economy elicited a concern for transformation amid the participants in the financial subdivision. A critical appraisal of their position led to the Central Bank of Nigeria (CBN) policy on "Cash-less economy" for Nigeria. This was pilot tested in Lagos from January 1, 2012. The intent was to ascertain Nigeria readiness for a full implementation across the country (Ndifon \& Okpa, 2014). The Central Bank of Nigeria $(\mathrm{CBN})$ introduced a new policy on cash-based transactions which stipulated a cash handling charge on daily cash withdrawals that exceed N500,000 (\$753.77) for Individuals and N3,000,000 $(\$ 15,075.39)$ for Corporate bodies. The new policy on cash-based transactions (withdrawals) in banks, aims at reducing the amount of physical cash circulating in the economy, and encouraging more electronic-based transactions.

A modern financial economy has three echelons, namely, the cash based echelon, cash-less and the cashless echelon. Most developing countries would normally transit from a 'cash-based' economic model to 'cash-less' economic model before achieving the pure state of a 'cashless' economic model (Odior \& Banuso, 2013). A cash-based economy is the one in which the daily payments and business activities are primarily transacted in physical notes and coins. Cashless economy, on the other hand, is an economy where the physical cash circulating in the economy is reduced while other forms of payment, especially electronic based payments (Point-ofsale, Mobile payment system, Internet banking ,Multifunctional ATM ,Electronic Funds Transfer) are used. Cash-less economy is a combination of the cash-based payment system and electronic payment systems (Ejiro, 2012). Usually at the commencement of cash-less economy, the cash-based payment exceeds the e-payment system, with time; the former then exceeds the latter which evolves to a cashless economy. Income levels in rural areas are so low that savings may not even be enough for transactions and precautionary purposes. In such a scenario, large and medium scale farmers have more opportunity of patronizing the banks. However government rural banking programs and other banking policies have made it possible for banks to be established in rural areas, some with ATM facilities. The slow acceptance of the ATM use by farmers might be traced partly to problems inherent in any attempt to make a major change in any system (banking sector). Trust is lacking in Nigerian agribusiness environment, agribusinesses are carried out on cash basis as cheques are not reliable and there is presently low penetration of point of sale (POS) terminals, hence farmers place less trust on the use of cheques but prefer cash instead (Agwu, 2012). High level of fraudulent activities through e-banking is a challenge, 
which the entire banking industry must resolve before cashless policy can be effective.

Cash as a legal tender can be used by everyone; this is not the case for alternative forms of money which is often linked to bank account, the low-income consumers such as small scale farmers may not have such account. A good percentage of small scale farmers are unbanked. They may also not be literate enough to master the technology. The high level of illiteracy in the country, low level of banking population and porous banking system have been identified by Dada (2011) as factors that would work against the cash-less society scheme. The problem with this situation of illiteracy is that majority of the small scale farmers belong to this group and they will have to depend on the literate few among the populace. (Dahunsi \& Akinyede, 2014). Security of funds is another challenging aspect of farmer's preference for cashless transactions. A situation where there is a communication breach during a transaction and the rural farmer does not receive an alert to confirm payment of goods; the buyer may be compelled to make multiple payments for the same transaction.

Aside the various challenges encountered by rural farmers in patronizing cashless activities, there are a variety of benefits expected to be derived by various stakeholders from an increased utilization of cash-less systems. The farmers will benefit through increased expediency; extra service options; reduced risk of cashrelated crimes; inexpensive access to banking services, access to credit and financial inclusion; the corporations benefit through faster access to capital; reduced revenue leakage; and reduced cash handling costs. While the Government benefits through increased tax collections; greater financial inclusion; increased economic development.

The significant factors influencing rural farmer's preference for cashless transactions in Imo state Nigeria will help policy makers establish a change in Nigerian payments systems. This is very important for economic growth and ultimately attainment of the Nigeria's Vision 2020. It will also reduce the huge costs of providing banking services. The money saved will be used to lend credit to Nigerians and finally it will help the Central Bank and commercial banks better manage our economy to ensure that our Monetary Policy works. Despite the prospective challenges and projections of the cashless policy introduced by the central bank of Nigeria, this study aims to estimate the determinants of rural farmer's preference for cashless transactions in Imo state Nigeria.

\section{DATA AND METHODS}

\section{Study area}

This research was conducted in Imo State, South-East of Nigeria. The state is over 4.8 million people (NPC 2006). The economy of the State depends primarily on agriculture and commerce. The major occupation of the people is farming. Their main cash crops grown in Imo state include oil palm, raffia palm, rice, groundnut, melon, cotton, cocoa, rubber, maize, etc. food crops such as yam, cassava, cocoyam and maize are also produced in large quantities.
The choice of the study area was fourfold. Firstly, the fervent economic activities of financial institutions including agriculture in the area. Secondly, there is a high degree of socio-cultural homogeneity in the study area as the inhabitants are mainly Igbos, known primarily for their farming activities, self-reliance and economic prowess, thirdly, the scarcity of empirical work done on farmers' preference for cash-less transactions and finally, there is a high concentration of farmers.

\section{Sampling Techniques and Data Collection}

A multistage sampling technique was used to select (90) respondents from the state. Firstly the state was divided into 3 agricultural zones, namely Okigwe, Owerri and Orlu Agricultural zones. Secondly, 2 local government areas (LGAs) were purposively selected from each agricultural zone based on the dominance of financial institutions with ICT facilities, to bring the total number of local governments areas selected to 6. Thirdly, one community was purposively selected from each of the local government based on the dominance of small scale farmers; this brings the total number of communities involved to 6 communities. In the fourth stage, 15 respondents were randomly selected from each of the 6 communities to bring the total number of respondents to 90. Data were collected from both primary and secondary sources of information. The major instrument used for primary data collection was structured questionnaire. The secondary data were collected through review of related literature such as text books, Journals, Bulletins, Seminar and Conference papers among others.

\section{Empirical Model}

The determinant of rural farmers' preference for cash-less transactions in Imo State, was achieved using logit model. A Logistic model is a univariate binary model. We use a binomial logistic regression model given that the dependent variable is dichotomous.

Following Gujarati (1995) the functional form for the model is as follows, while considering the following representations of farmer's preference for cash-less transactions (Eq. 1).

$$
\begin{aligned}
& P_{i}=E\left(Y=\frac{1}{x}\right) \\
& P_{i}=\left(1 / 1+e^{-\left(\beta_{0}+\beta_{i} x_{i}\right)}\right)
\end{aligned}
$$

For ease of exposition we write Equation (2) as,

$$
P_{i}=1 / 1+e^{-z i}-e^{z_{i}} / 1+e^{z i}
$$

where:

$\mathrm{z}_{\mathrm{i}}=\beta_{0}+\beta_{i} x_{i}$

This equation represents the cumulative logistic function which can be verified as $\mathrm{z}$ ranges from $-\infty$ to $+\infty$, while $P_{i}$ ranges between 0 and 1 and not 0 or 1 ; and $P_{i}$ is non-linear related to $\mathrm{z}_{\mathrm{i}}$ and $\beta_{s}$ so OLS can not be used in estimation of the model because it is a non-linear model. 
If $P_{i}$ is the probability of farmers preference for cashless transactions, then $1-P_{i}$ is the probability of farmers non-preference for cash-less transactions. Therefore, the probability that a given farmers prefers cash-less transactions is expressed in Equation (3), while the probability that a farmer doesn't prefer cash-less transactions is expressed by Equation (4).

$1-P_{i}=1 / 1+e^{z}$

Then we can modify Eq. (4) as

$\left(P_{i} / 1-P_{i}\right)=\frac{1+e^{z_{i}}}{1+e^{-z_{i}}}$

Now, $\left(P_{i} / 1-P_{i}\right)$ is simply the odds ratio in favor of farmers' preference for cash-less transaction, which happens to be the ratio of the probability of farmers who prefers cash-less transaction to the ratio of farmers who prefers otherwise. Finally taking the natural $\log$ of Equation (5) we obtain,

$\log \left(P_{i} / 1-P_{i}\right)=Z_{i}=\beta_{0}+\beta_{1} x_{1}+\cdots \beta_{8} x_{8}+e_{i} \cdots$

where:

$P_{i} \quad$ probability that a certain farmer prefers cash-less transactions;

$1-P_{i}$ probability that a certain farmer prefers otherwise;

$Z_{i} \quad$ function of explanatory variables $(\mathrm{x})$ which is also expressed as

$Z_{i}=\beta_{0}+\beta_{1} x_{1}+\beta_{2} x_{2}+\beta_{3} x_{3}+\cdots+\cdots \beta_{n} x_{n}+e_{i}$ where:

$\beta_{0}$ Intercept;

$\beta_{1}, \beta_{2}, \beta_{3}, \beta_{4} \ldots \beta_{n}$ slopes in the equation in the model; $x_{1}, x_{2}, x_{3} \ldots \ldots, x_{n}$ vectors of relevant characteristics influencing farmers' preferences for cash-less transactions;

$\mathrm{x}_{1}$ age of the farmer (years);

$\mathrm{x}_{2}$ gender;

$\mathrm{x}_{3}$ education Level. Measured by the total number of years the farmer spent in receiving formal education;

$\mathrm{x}_{4}$ monthly income $(\mathrm{N})$ in Nigerian Naira $(\mathrm{N}$ - the currency of Nigeria), Income of farmer from farming activities in the previous month;

$\mathrm{x}_{5}$ occupation (Dummy: $1=$ off farm jobs and $0=$ strictly farming occupation);

$\mathrm{x}_{6}$ security of transactions (Dummy: $1=$ secure and $0=$ insecure);

$\mathrm{x}_{7}$ user friendliness (Dummy: $1=$ friendly and $0=$ unfriendly);

$\mathrm{x}_{8}$ transaction cost/charge $(\mathrm{N})$;

$e_{i}$ error term.

\section{RESULTS AND DISCUSSION}

The result in Table 1 showed that the logistic model explains $72.30 \%$ of the total variation in the preference for cashless transaction by farmers in the study area. The chisquare statistics shows that the parameters included in the model were significantly different from zero at $5 \%$ level.
Age was negative and significant at 5\% level. This indicates that the higher the number years of the farmers, the less the lower their preference for cashless transaction. This study reveals that the young age group is more likely to prefer cashless transaction, whereas the older age group is less likely to prefer cashless transaction. These results are consistent with the findings of Flavián et al; (2006) who were of the opinion that Younger customers patronize cashless transaction due to a greater convenience, lower prices, and/or time savings. Sex of the farmer was negative and significant at $10 \%$ level. This indicates that the higher the number of males among the farmers, the lower their preference for cashless transaction. The results in this showed that males are less likely to patronize cashless transaction than females which could be as a result of the fact that women are often busy with household chores and would prefer a faster and convenient channel of transaction than their male counterparts. This result is contrary to the findings of Gao and Owolabi (2008) and Lichtenstein and Williamson's (2006) studies. Lichtenstein and Williamson (2006) noted that female users are more likely to patronize cashless transaction because these women have busy lives raising children and managing households and often working part or full time. Educational level was positive and significant at $1 \%$ level. This indicates that the higher the educational qualification of the farmers, the higher their preference for cashless transaction. Studies have shown that less educated people are more reluctant in using electronic payment services as a result of their inconvenience in using internet for doing their transactions (Banstola, 2007) and this may eventually impact their level of satisfaction with epayment services. In other words, people with higher education level are more adaptive to acceptance of cashless transactions. The farmers' perception on the security of using cashless transactions was positive and significant at 5\% level. This indicates that the more security of using the cashless transaction is guaranteed, the higher their preference of the cashless transaction. This is because you cannot play the game of soccer without a keeper! If the security of cashless transactions is not guaranteed then it's pointless patronizing cashless transactions. Lassar et al. (2005) in an investigation of factors influencing the use of e-banking, discovered that consumer innovativeness and personal characteristics are the key determinants of online banking adoption.

The ease of use (user friendliness) of cashless transactions was positive and significant at 5\% level. This indicates that the more user friendly (easier) the cashless transaction is the higher their preference level. Transaction charge was negative and significant at 5\% level. This indicates that the higher the transaction cost of cashless transaction the less the patronage of cashless transaction by the farmers in the study area and vice versa. There is great need for financial service providers to offer very attractive costs of transactions, to fast track cashless growth and patronage within Nigeria.

\section{CONCLUSIONS}

The banking industry has been a leader in the e-business world in recent years; the e-banking revolution has 
fundamentally changed the business of banking by scaling borders and bringing about new opportunities. It must be noted, however, that while e-banking provides many benefit $s$ to farmers, it also exacerbates rural banking risks.

Table 1: Parameter Estimate for the Logistic Regression Model

\begin{tabular}{llll}
\hline Variables & Coefficients & $\begin{array}{l}\text { Standard } \\
\text { Error }\end{array}$ & $\begin{array}{l}\text { Wald } \\
\text { Statistic }\end{array}$ \\
\hline Age & -0.186 & 0.074 & $6.313^{* *}$ \\
Sex & -1.717 & 1.032 & $2.770^{* * *}$ \\
Education & 0.337 & 0.104 & $10.449^{*}$ \\
Income & 0.000 & 0.000 & 0.067 \\
Occupation & 0.092 & 0.353 & 0.069 \\
Security & 2.010 & 0.926 & $4.711^{* *}$ \\
Userfrnd & 1.903 & 0.805 & $5.593^{* *}$ \\
Transacharge & -0.008 & 0.004 & $4.379^{* *}$ \\
Constant & 6.268 & 3.826 & 2.683 \\
Chi-square & $70.366^{*}$ & & \\
-2 Log likelihood & 54.356 & & \\
Nagelkerke R ${ }^{2}$ & 0.723 & & \\
\hline
\end{tabular}

Source: Computed from field survey data, 2014

$*$ = Significant at $1 \%, * *=$ Significant at $5 \%, * * *=$ Significant at $10 \%$

Nigeria is confronted with much impairment that affects the successful enactment of the cash-less policy initiatives. The ages, education level of the farmer, user friendliness, the security guaranteed on the use of ebanking facilities, and the transaction charge by financial institutions are major setbacks towards the transition from a cash-based economy to cash-less economy. Therefore, the banks should carry awareness campaigns so as to enlighten the farmers especially elderly farmers on the benefits of cash-less transactions, they should also organize financial literacy programs for farmers, enlighten the farmers of their guaranteed security in cash-less transactions. In addition the banks should make cash-less transactions more user friendly for farmers considering the fact that most farmers aren't well educated. Finally the transaction charges should be moderated by the banks so as to encourage farmers' patronage on cash-less transactions so as to increase customer satisfaction, and improve easy access to their accounts whenever and where ever, they want.

\section{REFERENCES}

AGWU, E. (2012). A Qualitative Study of the Problems and Prospects of Online Banking in Developing Economies - Case of Nigeria. Journal of Internet Banking and Commerce, vol. 17, no. 3, pp 1-20.

BANSTOLA, A. (2007), Prospects and Challenges of Ebanking in Nepal, Journal of Nepalese Business Studies, Vol. IV, No. $1 . \quad$ DOI: http://dx.doi.org/10.3126/jnbs.v4i1.1034

CGIAR (1995). Renewal of the CGIAR: sustainable agriculture for food security in developing countries. Ministerial-level Meeting, Luceme, Switzerland, CGIAR, Washington, D.C. USA. Pp. 133.
DADA, P. \& ORONSAYE, S. (2011). As Lagosians Geer up for Cashless Economy. http://www.leadership.ng/.../lagosians_gear_cash.

DAHUNSI, F.M. \& AKINYEDE, R.O. (2014). ICT Perspectives on the Feasibility Analysis of the Cashless Economy in Nigeria. African Journal of Computing and ICT, Vol 7, No. 5.

EJIRO, O. (2012). What Nigerians Think of the Cashless Economy Policy. Nigerian Journal of Economy, vol. 4, no. 6, pp. $97-102$.

FLAVIÁN, C., GUINALÍU, M., \& GURREA, R. (2006). The Influence of Familiarity and Usability on Loyalty to Online Journalistic services: The role of user experience. Journal of Retailing and Consumer Services, 13 (5), pp. 363-375. DOI: 10.1016/j.jretconser.2005.11.003.

GAO, P. and OWOLABI, O. (2008). Consumer adoption of Internet banking in Nigeria. International Journal of Electronic Finance, 2 (3), pp. 284-299. Doi:10.1504/IJEF.2008.020598

GUJARATI, D. N. (1995). Basic econometrics. 3rd edition. McGraw-Hill, Inc., 568.

LASSAR, W.M., MANOLIS, C. and LASSAR S.S. (2005). The Relationship between Consumer Innovativeness, Personal Characteristics, and Online Banking Adoption, International Journal of Bank Marketing, Vol. 23, No. 2:176-199,

LICHTENSTEIN, S. and WILLIAMSON, K. (2006). Understanding consumer adoption of internet banking: an Interpretive study in the Australian banking context. Journal of Electronic Commerce Research, 7 (2), pp. 5066.

NATIONAL POPULATION COMMISSION (2006) National Population Census 2006

NDIFON, E. and INAH, I. (2014). The Workability of the Cash-less Policy Implementation in Nigeria. Journal of Economics and Sustainable Development. Vol.5, No.17, pp.179-191

NWEKE, F. (2012). Nigeria in 2012: The Vision of Cashless Economy. Delivered September 17th at the J-K Gadzama \& Partners LLP 2012 Annual Public Lecture.

ODIOR, E. S. and BANUSO, F. B. (2013). Cashless Banking in Nigeria: Challenges, Benefits and Policy Implications. European Scientific Journal, vol. 8, no. 12, pp. 289-316

OGBONNA J.U. (2000). Imo State in Nigeria: A People United, A Future Assured, Survey of States in A.B Mamman, J.O. Oyebanji, S.W. Petters (ed), Volume 2. Federal Ministry of Information. Millennium Edition. Published by Gabumo Publishing Company. Ltd. In collaboration with the Presidency, Abuja.

OMOSE, K. (2011). Deconstructing CBN Cashless Policy. available at www.mobilemoneyafrica.com 